is moistened, and a roller charged with a greasy ink is passed over it, the ink is taken up by the print more readily where the light has produced the most change and the water has been the least absorbed. The use of rollers for the application of the ink soon gave way in favour of brushes. This process commended itself to many photographers, especially those who desired to "control " their prints, that is, to produce what they desired rather than what they were able to secure by photographic methods, for it is possible to put on much or little ink, and to reduce or increase the quantity in the various parts of the print as the taste of the worker may dictate. Obviously a wide choice of colours is available, and the method has the advantage of giving the peculiar richness and depth of tone associated with oil colours.

About a year ago it was found possible to render bromide enlargements available for this process, the silver image in the enlargement effecting the reduction of the bichromate. Thus no large negative is needed, and no exposure to light after the bromide enlargement has been made. Mr. F. J. Mortimer calls this last method of work the "bromoil " process, and he has now on view at the house of the Royal Photographic Society, 66 Russell Square, more than fifty examples of his own work. The exhibition will remain open, free on presentation of visiting card, daily from ir a.m. to 5 p.m., until June 8. Mr. Mortimer has been known for a considerable time as the producer of fine marine and coast-scenery photographs, but here he shows also landscapes and portraits of various kinds. Those who are interested in such methods of work wil get a better idea of the possibilities of the "bromoil" process by a study of these examples than they have ever had an opportunity of getting before.

\section{ARBORICULTURE IN GERMANY.'}

THE German Arboricultural Society came into existence in the year 1892 , and now has a membership of 1800 of whom 120 attended its annual meeting in August, 1908, in Alsace Lorraine; Strassburg and Colmar being its headquarters. The president is Count Schwerin, who is ably helped by the secretary, L. Beissner, the conifer expert. The report just issued gives a detailed account of the meeting. The first three days were devoted to the reading of papers now published. Then followed visits to private parks, where many fine exotic and native trees, some of which are illustrated in the report, were seen. Each member, who was himself listed and conspicuously numbered, received a numbered list of the trees worthy of note in each centre visited. The list gave the name, girth, height, and age of each tree, with further remarks in some cases.

The lists embodied in the report may serve as an indication of the perfection of arrangement which characterised the meeting. Everything was planned to the minute, and nothing was allowed to interfere with the programme. Thus at Ollweiler Prof. Engler was in danger of being left behind after a hurried inspection of a fine specimen of Quercus sessiliflora, 250 years old. La Schlucht and Hoheneck gave a peep into the forests on the slopes of the Vosges Mountains. This district, with Longuemer and Retournemer, was also visited by the botanists fresh from the Botanical Congress at Strassburg, and was fu'l of interest.

A few only of the articles in the report can be noticed. In addition to many contributions by the president, including one on the hardiness of certain trees, and one by Beissner on conifers, C. S. Sargent, an honorary member, gives an illustrated account of the Arnold Arboretum, Koehne writes on Taxodium, Forster on exotic trees, Berg on Pseudotsuga Douglasii in Europe, while St. Olbrich and Hübner write on trees suitable for avenues and towns, and Sprenger and Rehder on new or rare arboreous plants.

Following on more than twenty important papers there are many smaller contributions. One of these may be noticed. Unger, just returned from a residence of twenty years in Japan, proposed the cultivation of Broussonetia

1 Mitteilungen der deutschen dendrologischen Gesellschaft. No. 17, 1908. Pp. 285 ; with many illustrations. (Bonn-Poppelsdorf: L. Beissner, Geschäftsführer der Gesellschaft.) Price 5 marks. papyrifera for the supply of Japanese paper. As twenty degrees of frost is fatal to the plant, Germany was declared by experience unsuitable for the industry. Several pages are devoted to descriptions, in Latin in many cases, of new species or forms. A useful feature is a correspondence section for the supply of information on such subjects as Platanus diseases, and pitch pine. A place is also found for reviews of books on trees. Obituary notices appear, including one on John Booth, a Teutonic Scot, who strove successfully to introduce exotic timber trees into Germany, and one on George Nicholson, of Kew. Altogether the publication is astonishingly rich in contents of wide and general interest, and is very cheap.

A curious feature of the report is the entire absence of any reference to the many beautiful illustrations, there being sixteen full-page ones and many others incorporated in the text. Members of the Society, by payment of an annual subscription of five marks, obtain the report, certain privileges at the meeting, and supplies of packets of seeds as well as of living plants. This result is mainly due to the enthusiastic devotion and organising skill of the president, who has personally made all the detailed arrangements for the meeting at Cottbus in I909, and provided the necessary particulars for two alternative places of meeting in Igro. The society would be delighted, I learnt, to visit the British Isles in the company of British arboriculturists. Cannot this be arranged for by the three British arboricultural societies?

A re-issue of the reports for the year 1892-1901, in one volume of 500 pages, at not more than nine marks, is offered for subscription.

T. J.

\section{GROWTH OF NERVE FIBRES.}

$T H E$ view that each nerve fibre develops as an independent outgrowth from a nerve-cell, finally becoming united to other tissues (e.g. muscle fibres) in the periphery of the body is associated especially with the name of His, and has been accepted by the majority of embryologists. Those who have worked at the question of nerve repair or have studied the mechanism of the regeneration of nerve fibres which leads to restoration of functions are divided into two camps; the majority hold, as Waller originally taught, that the nerve fibres grow in a distal direction from the cut stump attached to the central nervous system, ultimately finding their way into the peripheral segment. A minority of researchers hold the contrary view, namely, that restoration occurs in the peripheral segment independently of connection with the central nervous system.

Within the last year, Mr. Ross Harrison, of Yale, has demonstrated the correctness of the views of $\mathrm{His}$ in a very remarkable way. He has actually seen the fibres growing outwards in embryonic structures. Pieces of the primitive nervous tube which forms the central nervous system were removed from frog embryos and kept alive in a drop of lymph for a very considerable time; the cilia of the neighbouring epidermic cells remained active for a week or more; embryonic mesoblastic cells in the vicinity were seen to become transformed into striated muscular fibres, and there was therefore no doubt that even under these artificial conditions-rendered necessary for microscopic purposes-life and growth were continuing. From the primitive nervous tissue, and from this alone, nerve fibres were observed growing and extending into the surrounding parts. Each fibre shows faint fibrillation, but its most remarkable feature is its enlarged end, which exhibits a continual change of form. This amœboid movement is very active, and it results in drawing out and lengthening the fibre to which it is attached, and the length of the fibre increases at the rate of about I micromillimetre per minute. Those interested in this subject should refer to Mr. Harrison's last paper, published in the Anatomical Record (Philadelphia, December, 1908), where they will find figures representing the growing fibres in various lengths drawn at intervals of half an hour or thereabouts.

Such observations show beyond question that the nerve fibre develops by the overfiowing of protoplasm from the central cells and thus give us direct ocular evidence in 